\title{
Maturação do sistema auditivo central em crianças ouvintes normais $* * * *$
}

\author{
Central hearing system maturation in normally hearing children
}

\begin{abstract}
Luzia Maria Pozzobom Ventura*
Orozimbo Alves Costa Filho**

Kátia de Freitas Alvarenga***
\end{abstract}

*Fonoaudióloga. Mestre em Fonoaudiologia pela Faculdade de Odontologia de Bauru da Universidade de São Paulo (USP). Fonoaudióloga do Centro de Pesquisas Audiológicas do Hospital de Reabilitação de Anomalias Craniofaciais da USP. Endereço para correspondência: Centro de Pesquisas Audiológicas do Hospital de Reabilitação de Anomalias Craniofaciais da USP. Rua Silvio Marchione, 3-20 - Vila Universitária Caixa Postal 1501 - CEP 17012-900 (poventi@ig.com.br).

**Médico Otologista. Professor Titular do Departamento de Fonoaudiologia da Faculdade de Odontologia de Bauru USP.

***Fonoaudióloga. Pós-Doutora em Avaliação Audiológica Infantil pela University of Manchester. Professora Associada do Departamento de

Fonoaudiologia da Faculdade de Odontologia de Bauru - USP.

****Trabalho Realizado na Clínica do Curso de Fonoaudiologia da Faculdade de Odontologia de Bauru - USP.

Artigo Original de Pesquisa

Artigo Submetido a Avaliação por Pares

Conflito de Interesse: não

Recebido em 03.11.2008.

Revisado em 03.03.2009.

Aceito para Publicação em 04.05.2009.

\begin{abstract}
Background: the long latency auditory evoked potentials (LLAEP) provide objective data about the function of hearing cortical structures. Aim: to characterize the maturation of the central hearing system in normally hearing children. Method: record of LLAEP of fifty-six subjects with hearing tresholds within normal limits, of both genders, being 46 children and 10 adults. With the availability of two recording channels, one was directed to register the LLAEP and the other, to record the artifact generated by ocular movement, aiming at its control. The potentials were recorded with subjects in an alert state, through electrodes positioned in $\mathrm{Cz}$ (active) and A2 (reference), and the ocular movements, through electrodes in the left supra and infra-orbital positions; the ground electrode was placed in A1. The morphology and the values of latency and of amplitude for components P1, N1 and P2, according to age, were analyzed. In order to verify the reproducibility of the recorded potentials, a double blind study was carried out, by introducing the analysis of another evaluator. Results: the double blind study did not present statistically significant differences between the analyses. With the increase in age there was an improvement in the morphology and a decrease in the latency values of components P1, N1 and P2. Also there was a decrease in the amplitude of component P1 and no variation in the amplitude values was observed for components N1 and P2. No statistically significant difference was observed between genders. Conclusion: the maturational process of the central hearing system occurs gradually, being the greatest changes observed when comparing children and adults.
\end{abstract}

Key Words: Hearing; Maturation; Auditory Evoked Potentials.

\section{Resumo}

Tema: os potenciais evocados auditivos de longa latência (PEALLs) fornecem dados objetivos sobre a funcionalidade das estruturas centrais auditivas. Objetivo: caracterizar a maturação do sistema auditivo central em crianças com audição normal. Método: registro dos PEALLs de 56 indivíduos ouvintes normais, de ambos os sexos, sendo 46 crianças e 10 adultos. Com a disponibilidade de dois canais de registro, um foi destinado à captação dos PEALLs e outro, ao registro do artefato gerado pelo movimento ocular, visando ao seu controle. Os potenciais foram registrados com os indivíduos em estado de alerta, por meio de eletrodos posicionados em $\mathrm{Cz}$ (ativo) e A2 (referência) e os movimentos oculares, por eletrodos em posição supra e infra-orbital esquerda; o eletrodo terra foi colocado em A1. Foram analisados a morfologia e os valores de latência e amplitude dos componentes P1, N1 e P2, de acordo com a idade. Para verificar a reprodutibilidade dos registros, foi realizado um estudo duplo-cego com a introdução da análise de outra avaliadora. Resultados: o estudo duplo-cego não mostrou diferenças estatisticamente significantes entre as análises. Com o avanço da idade, houve melhora na morfologia e diminuição nos valores de latência dos componentes P1, N1 e P2. O componente P1 teve sua amplitude diminuída e não foi observada variação nos valores de amplitude dos componentes N1 e P2. Não foi observada diferença estatisticamente significante entre os sexos. Conclusão: o processo maturacional do sistema auditivo central acontece de maneira gradativa, sendo as maiores modificações observadas ao se comparar crianças e adultos.

Palavras-Chave: Audição; Maturação; Potenciais Evocados Auditivos. 


\section{Introduction}

It is clear that a critical period for the acquisition and development of language relating to treatment of children with hearing impairment exists. Clinical findings show that children with such impairments who receive appropriate and earlier intervention present better hearing and better language performance than those who start the process in more advanced ages 1 .

In recent studies, the electrophysiological assessment has been showed to be efficient in investigating the functioning of the auditory system and in providing objective data on the benefit of early intervention, corroborating to clinical evaluation2.

Among available tests, the Long Latency Auditory Evoked Potentials (LLAEPs) are of great value for providing objective data on the functionality of auditory cortical structures and, consequently, when applied to normal hearing individuals in different age groups, quantify the maturity period of the central hearing system.

Within this context, this study aimed to characterize the maturational development of the central hearing system in normal hearing children through the analysis of the P1, N1 and P2 components in order to provide initial parameters to be used on further studies and in clinical routine.

Although several international studies have been conducted with this aim3-20, the present study is nationally of greater importance for presenting an assessment protocol with the focus towards national clinically available resources and also when considering the limitation of national literature on this topic - only one study that addresses the central auditory development in normal subjects was found 21 .

\section{Method}

This study was approved by the Research Ethics Committee of the institution where data collection was performed under number 99/2006. Adult participants and the parents of children who participate in the study agreed to study conduction and to the dissemination of its results, according to Resolution 196/96, by signing a Free and Informed Consent Form.

\section{Subjects}

The sample was composed by 56 individuals of both genders - 46 children aging from 3:0 to 12:0 years and 10 adults, aging between 20:0 and 30:5 years.
Inclusion criteria were: absence of hearing and educational complaints; absence of complaints related to auditory processing disorder; absence of neurological disorders; and presence of hearing within normal limits, confirmed by audiometry and measurement of acoustic impedance.

\section{Assessment process}

The search for the LLAEPs was conducted through the equipment Smart EPUSB Jr from Intelligent Hearing Systems, with two channels of recording, which was calibrated at hearing level hearing (dBHL) prior to beginning the study. The study was conducted in an acoustically and electrically treated room, with the subjected comfortably seated on a chair.

As the maintenance of the alert state is a prerequisite to the capture of LLAEPs3-9, the subjects were watching a silent video, which made necessary the controlling for the artifacts generated by eye movement.

With this aim, one channel captured the LLAEPs (Channel A) and the other (Channel B) captured eye movements and blinking. In channel $\mathrm{A}$, the active electrode was positioned at $\mathrm{Cz}$; the reference electrode at the right ear lobe (A2); the ground electrode was placed at the left ear lobe (A1). In channel B, the active electrode was placed at the left supra-orbital position and the reference electrode at the left infra-orbital position. With this electrode arrangement, the amplitude of vertical eye movement - the only one possible of being recorded that presents amplitude relevant to $\mathrm{Cz}$ - and blink amplitude were verified before the collection of the potentials - in order to define the level of rejection used in each test and, consequently, the non capture of eye movements in order for a non interference on the LLAEPs registration occur.

The parameters of response stimulation and recording were:

. click stimulus, condensed polarity, with duration of 100 ?s and $526 \mathrm{~ms}$ of inter-stimuli interval, presented on the right ear through the insertion earphone, with $70 \mathrm{dBNA}$ in intensity and presentation rate of 1.9 stimuli per second;

. band-pass filter of $1-30 \mathrm{~Hz}, 100.0 \mathrm{~K}$ gain on the two channels - 512 pro-mean stimuli and window of analysis of the response of from- $100 \mathrm{~ms}$ prior-stimulus to $500 \mathrm{~ms}$ post-stimulus were used;

. disposable ECGelectrodes from MEDITRACETM200 and conductive EEG paste from 20TM were used and placed after the cleaning of the skin of the subject with Abrasive Gel for ECG / EEG from NUPREP. The impedance level was maintained at between 1-3Kohms. 
Data analysis

The records of the potentials were analyzed, considering the variables age, gender, latency and amplitude of components $\mathrm{P} 1, \mathrm{~N} 1$ and $\mathrm{P} 2$. In order to verify the reproducibility of the potentials obtained, a double-blinded study was conducted through the insertion of the trace analysis by an evaluator with experience in Electrophysiology, which allowed the comparison to the records analyzed by the author of the research.

The agreement limit between the two evaluators and its confidence intervals were calculated using the Bland and Altman22 method and the test of normality used to calculate the difference distribution was the Shapiro-Wilk23. To study the association between latency and amplitude, we used a simple linear regression model24 between latency and amplitude of LLAEPs and age. To test the hypothesis of homoscedasticity of the linear regression model, we used the Levene modified test24, considering the group of children and adults. In cases where failure of this assumption was detected, the groups were compared using the Student $\mathrm{t}$ test for independent samples.

\section{Results}

There was no evidence of bias on the analysis of concordance between evaluators. The error rate between the two evaluators was about $6 \mathrm{~ms}$ for the latency and 0,20?V for the amplitude.

The morphology of the traces was characterized by an increase in their complexity, with better definition of the components with age increase.
Morphological variations were observed, such as the duplicity of the $\mathrm{N} 1$ component in the age of four, five and ten years, and a salience of the P1 component in the ages of four and five years.

Although in none of the cases the absence of all components could be observed, the presence of the components $\mathrm{P} 1, \mathrm{~N} 1$ and $\mathrm{P} 2$ varied according to age, being P1 the component of higher occurrence in younger individuals.

The results of linear regression models that determine the association of latency and amplitude with age are shown in Table 1.

Because as failure on homoscedasticity was noted - that is, different variability between the groups of adults and children - for the values of latency of $\mathrm{N} 1$ and $\mathrm{P} 2$ components, the groups were compared using the Student $\mathrm{t}$ test, which showed that the values of latency in adults were lower on an average of 33 to $69 \mathrm{~ms}$ for the N1 component, and of 37 to $80 \mathrm{~ms}$ for the $\mathrm{P} 2$ component.

Graphs 1 and 2 show the adjustment of the linear regression model to the data of latency and amplitude, respectively, with expected line for each component displayed.

The results of linear regression analysis showed the occurrence of a statistically significant association between the latency of the P1 component and age $(\mathrm{p}=0.01)$.

The results showed the occurrence of a statistically significant association only between the amplitude of P1 and age, and no significant variation in the values of amplitude of components $\mathrm{N} 1$ and $\mathrm{P} 2$.

TABLE 1. Linear Regression Models.

\begin{tabular}{|c|c|c|c|c|c|c|}
\hline Variable & Place & Coefficient & Estimative & $\begin{array}{l}\text { Standard- } \\
\text { Error }\end{array}$ & $\mathbf{p}$ & $\begin{array}{c}\text { Modified } \\
\text { Levene Test }\end{array}$ \\
\hline \multirow{6}{*}{ Latency } & \multirow{2}{*}{$\mathrm{P}_{1}$} & Interception & 99 & 6 & $<0,001$ & \multirow{2}{*}{0,560} \\
\hline & & Age & $-1,6$ & 0,4 & 0,001 & \\
\hline & \multirow{2}{*}{$\mathrm{N}_{1}$} & Interception & 168 & 10 & $<0,001$ & \multirow{2}{*}{0,001} \\
\hline & & Age & $-3,1$ & 0,8 & $<0,001$ & \\
\hline & \multirow{2}{*}{$\mathrm{P}_{2}$} & Interception & 228 & 12 & $<0,001$ & \multirow{2}{*}{0,000} \\
\hline & & Age & $-3,3$ & 1,0 & 0,001 & \\
\hline \multirow{6}{*}{ Amplitude } & \multirow{2}{*}{$\mathrm{P}_{1}$} & Interception & 1,11 & 0,11 & $<0,001$ & \multirow{2}{*}{0,235} \\
\hline & & Age & $-0,02$ & 0,01 & 0,042 & \\
\hline & \multirow{2}{*}{$\mathrm{N}_{1}$} & Interception & $-1,16$ & 0,15 & $<0,001$ & \multirow{2}{*}{0,330} \\
\hline & & Age & 0,02 & 0,01 & 0,221 & \\
\hline & \multirow{2}{*}{$\mathrm{P}_{2}$} & Interception & 0,61 & 0,11 & $<0,001$ & \multirow{2}{*}{0,455} \\
\hline & & Age & 0,01 & 0,01 & 0,441 & \\
\hline
\end{tabular}


GRAPH 1. Dispersion between latency and age values with expected line.

P1

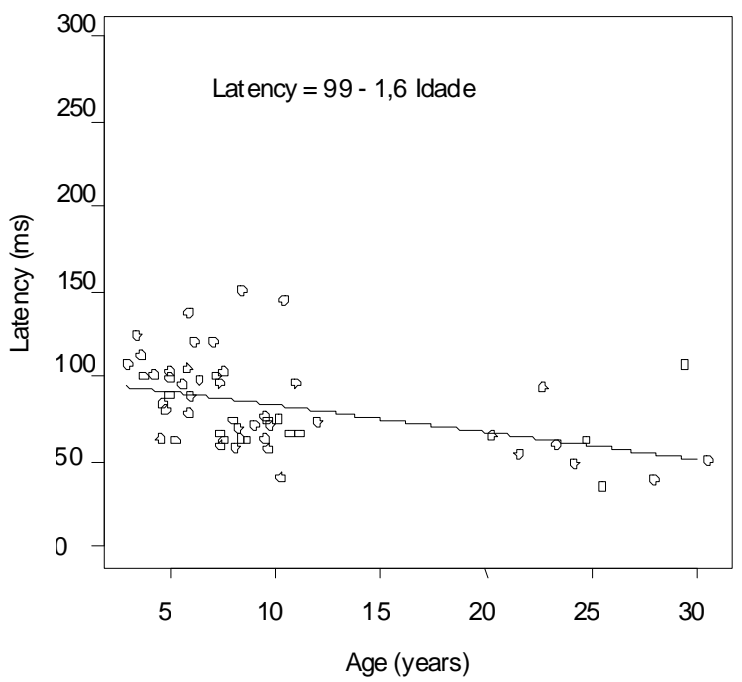

P2

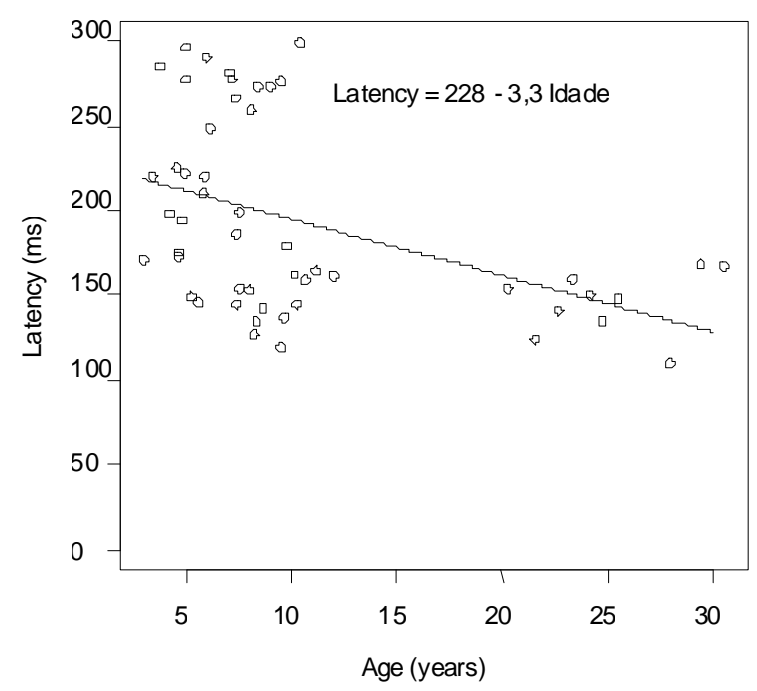

N1

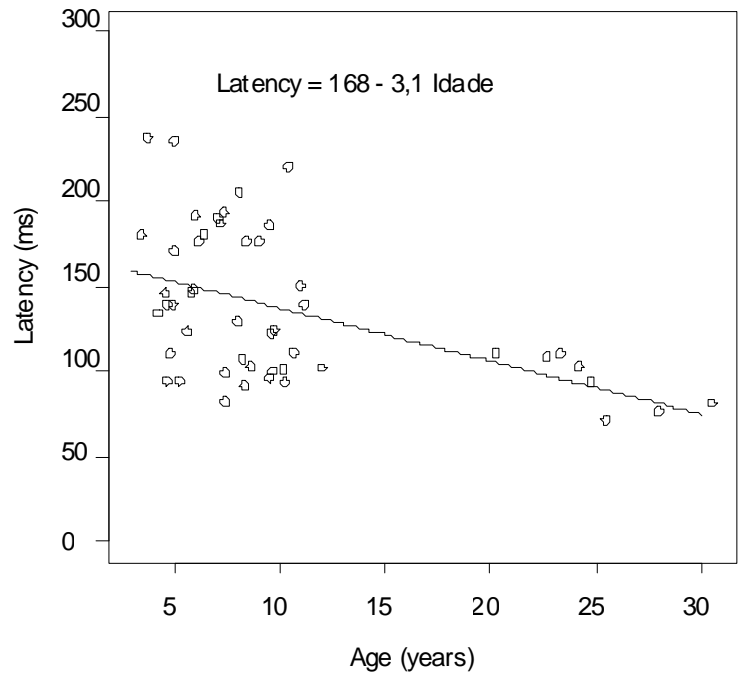


GRAPH 2. Dispersion between amplitude and age values with expected line.

P1

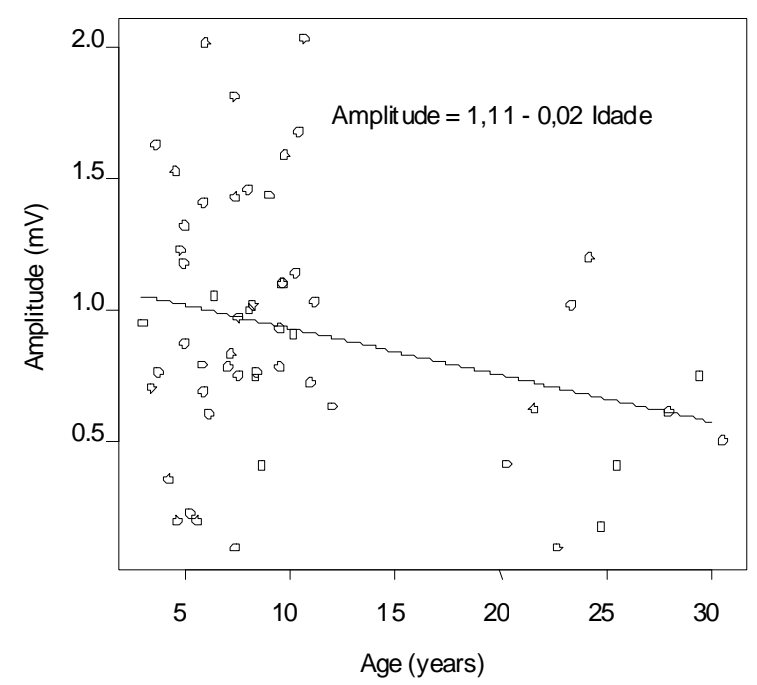

P2

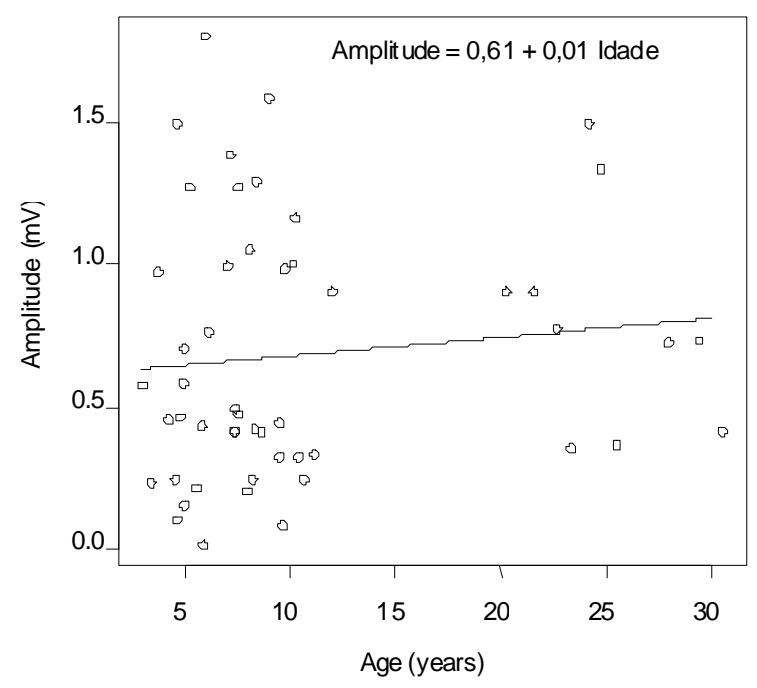

N1

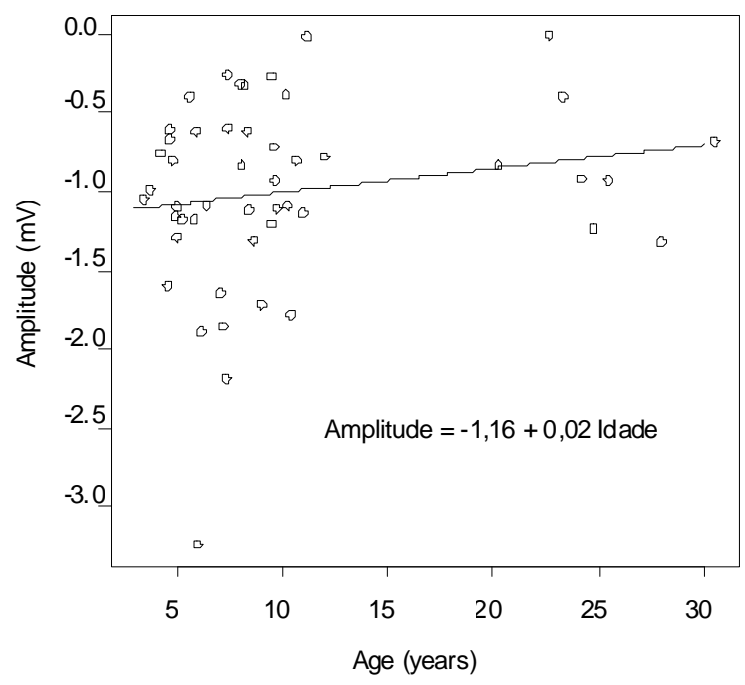

Age (years)

\section{Discussion}

This study brought to the national literature the knowledge of maturational process of the central hearing system, considering the technological resource usually available in Brazilian clinics. Studies that analyze these potentials are predominantly international, performed with equipments with different channels that we usually do not have in our clinical or academic practice.

Comparing the age ranges evaluated, in children, despite the possibility of recording all the components, it was noticed that the P1 component was the most frequent one, and that the components $\mathrm{N} 1$ and P2 are defined with age advance until adulthood, which was also observed in literature3$6,8,10-11$. Variations in morphology were found until the age of ten, characterized by an arm on the P1 component, preceding the $\mathrm{N} 112$, and a negative component along the N15. With the advance of age, an improvement on the components morphology was observed, which is in agreement with consulted literature 10,13 . This may be resultant from the increase on synchronization of neuronal 
activity and from the establishment of effective structural connections 10 .

For the variables latency and amplitude of all components, no statistically significant difference was found between genders ( $p>0.05$ ), which is in agreement with other studies 21 , showing that the maturational process of the central hearing system is similar regardless of gender.

With regard to age, it is not clear on the literature what really occurs to amplitude and latency of the components $\mathrm{P} 1, \mathrm{~N} 1$ and $\mathrm{P} 2$; but, it is apparent that this is an important variable on the analysis of these components. Differences on results achieved by different studies can be justified by different methods - however, without the identification of the parameter responsible for each variation.

In this study (Graph 2) great variability on the values of amplitude for components $\mathrm{P} 1, \mathrm{~N} 1$ and $\mathrm{P} 2$ in each assessed age was observed, which was also demonstrated in literature for the P24 component. Comparing the ages, a decrease in amplitude values of component P1, with a decrease rate of 0,02 ? $\mathrm{V}$ per year was observed. This was not observed for the $\mathrm{N} 1$ and $\mathrm{P} 2$ components.

With respect to the latency values, we observed a statistically significant association with age for the P1 component, with an expected drop in the value of latency of $1.6 \mathrm{~ms}$ per year (Table 1 and Graph 1). For the latency of N1 and P2 components, statistically significant difference was observed between children and adults, being the average latency in adults lower on an average from 33 to $69 \mathrm{~ms}$ for the $\mathrm{N} 1$ component, and from 37 to $80 \mathrm{~ms}$ for the $\mathrm{P} 2$ component. Reduction in latency values of all components was also observed in other studies3,6,8-10,14-15.

It is known that the reduction in latency values is related to the myelinization of central auditory structures, which is only completed at 12 years of age 25 and can be reflected on the stabilization of the values obtained with the use of LLAEPs26.

Some studies showed that the decline in the latency of $\mathrm{N} 1$ and $\mathrm{P} 2$ components occurs from the age of 10 years, building up to the age of 205,16, and that the values of latency of components P1 and $\mathrm{N} 1$ approximate to those found in adults, from the age of 15 until 20 years5, 11.17, indicating that the maturational process of sites generators of these potentials is only completed in the second decade of life. This may explain the difference between the latency values found in the sample between children and adults.

Comparing latency values between these groups, great variability on ages earlier than 12 years is observed. This variability disappears in the adult group, which was also observed in other estudos 10. When analyzing Graph 1, we observe a decrease in the values of latency of all components with the increase of age, although this model can only be used for the P1 component. Therefore, we find that the maturation of central hearing system, although subject to considerable changes in puberty, starts during the first years of life and stabilizes in adulthood on a gradual and linear manner.

Several variables that can influence the registration of LLAEPs can be identified in the literature such as: assessment condition; physical status of the subject; inherent differences; variability of sites generators of potential; and variation in synchronization 18 , besides methodological factors such as rate of stimulus presentation, inter-stimuli range and positioning of electrode6,8,14,16,18-20. Nevertheless, in this study, we demonstrated the association between age and the components $\mathrm{P} 1, \mathrm{~N} 1$ and $\mathrm{P} 2$, which reflects the maturational process of the central hearing system.

\section{Conclusion}

The maturational process of the central hearing system occurs gradually and is characterized by: increase on the morphological definition of LLAEPs; decrease of the latency values of all components with the largest changes observed when comparing children and adults; reduction in variability of latency values with age increase; decrease of the amplitude value of component P1, and lack of variation in amplitude values of components $\mathrm{N} 1$ and $\mathrm{P} 2$. 


\section{References}

1.Yoshinaga-Itano C, Sedey AL, Coulter DK, Mehl AL. Language of early- and later-identified children with hearing loss. Pediatrics. 1998 Nov 102(5):1161-71.

2. Sharma A, Dorman MF, Spahr AJ. A sensitive period for the development of the central auditory system in children with cochlear implants: implications for age of implantation. Ear Hear. 2002;23(6):532-9.

3. Kraus N, McGee T, Carrell T, Sharma A, Micco A, Nicol T. Speech-evoked cortical potentials in children. J Am Acad Audiol. 1993;4:238-48.

4. Ponton CW, Eggermont JJ, Khosla D, Kwong B, Don M. Maturation of human central auditory system activity: separating auditory evoked potentials by dipole source modeling. Clin Neurophysiol. 2002;113:407-20.

5. Sharma A, Kraus N, McGee TJ, Nicol TG. Developmental changes in $\mathrm{P} 1$ and $\mathrm{N} 1$ central auditory responses elicited by consonant-vowel syllables. Electroenceph clin Neurophysiol. 1997;104:540-5.

6. Ceponiene R, Rinne T, Näätänen R. Maturation of cortical sound processing as indexed by event-related potentials. Clin Neurophysiol. 2002;113:870-82.

7. Liasis A, Bamiou DE, Campbell P, Sirimanna T, Boyd S, Towell A. Auditory event-related potentials in the assessment of auditory processing disorders: a piloty study. Neuropediatrics. 2003;34:23-9.

8. Gilley PM, Sharma A, Dorman M, Martin K. Developmental changes in refractoriness of the cortical auditory evoked potential. Clin Neurophysiol. 2005;116:648-57.

9. Kummer P, Burger M, Schuster M, Rosanowski F, Eysholdt U, Hoppe U. Cortical auditory evoked potentials to acoustic changes in speech stimuli in children. Folia Phoniatr Logop. 2007;59(5):273-80.

10. Albrecht R, Suchodoletz WV, Uwer R. The development of auditory evoked dipole source activity from childhood to adulthood. Clin Neurophysiol. 2000 Dec 111(12):2268-76.

11. Ponton CW, Don M, Eggermont JJ, Waring MD, Masuda A. Maturation of human cortical auditory function: differences between normal-hearing children and children with cochlear implants. Ear Hear. 1996 Oct 17(5):430-7.

12. Gomes H, Dunn M, Ritter W, Kurtzberg D, Brattson A, Kreuzer JA, Vaughan Jr HG. Spatiotemporal maturation of the central and lateral N1 components to tones. Brain Res Dev Brain Res. 2001 Aug 129(2):147-55.

13. Bernal J, Harmony T, Rodríguez M, Reyes A, Yánez G, Fernández T, et al. Auditory event-related potentials in poor readers. Int J Psychophysiol. 2000;36:11-23.
14. Coch D, Skendzel W, Neville HJ. Auditory and visual refractory period effects in children and adults: an ERP study. Clin Neurophysiol. 2005;116:2184-203.

15. Mueller V, Brehmer Y, Oertzen TV, Li S, Lindenberger U. Electrophysiological correlates of selective attention: a lifespan comparison. Neuroscience [serial on line]. 2008;9(18). Encontrado em: URL: http:// www.biomedcentral.com/1471-2202/9/18.

16. Lauffer H, Miller C, Pröschel U, Wenzel D. Simultaneous recording of brainstem and cortical acoustic evoked potentials in children: methodical aspects and normative data. Eur J Pediatr. 1993 Aug 152(8):682-5.

17. Fuchigami T, Okubo O, Fujita Y, Okuni M, Noguchi Y, Yamada T. Auditory event-related potentials and reaction time in children: evaluation of cognitive development. Dev Med Child Neurology. 1993;35:230-7.

18. Tonnquist-Uhlén I, Borg E, Spens KE. Topography of auditory evoked long-latency potentials in normal children, with particular reference to the $\mathrm{N} 1$ component. Electroenceph Clin Neurophysiol. 1995 July 95(1):34-41.

19. Bruneau N, Roux S, Guérin P, Barthélémy C, Lelord G. Temporal prominence of auditory evoked potentials (N1 wave) in 4-8-year-old children. Psychophysiol. 1997;34:32-8.

20. Takeshita K, Nagamine T, Thuy DHD, Satow T, Matsuhashi M, Yamamoto J, et al. Maturational changes of parallel auditory processing in school-aged children revealed by simultaneous recording of magnetic and electric cortical responses. Clin Neurophysiol. 2002;113:1470-84.

21. Frizzo ACF, Junqueira CAO, Fellipe ACN, Colafêmina JF. Potenciais evocados auditivos de longa latência no processo maturacional. ACTA AWHO. 2001;20(2):74-80.

22. Bland JM, Altman DG. Measuring agreement in method comparison studies. Stat Methods Med Res. 1999;8:135-60.

23. Shapiro SS, Wilk MB. An analysis of variance test for normality (complete samples). Biometrika. 1965;52:591-611.

24. Neter J, Kutner MH, Nachtshein CJ, Wasserman W. Applied linear statistical models. 4th ed. New York: McGraw-Hill/Irwin; 1996.

25. Eggermont JJ, Ponton CW. Auditory-evoked potential studies of cortical maturation in normal hearing and implanted children: correlations with changes in structure and speech perception. Acta Otolaryngol. 2003 Jan 123(2):249-52.

26. Musiek F, Verkest S, Gollegly K. Effects of neuromaturation of auditory evoked potentials. Semin Hear. 1988 Feb 9(1):1-13. 